\title{
Egl Nine Homolog 2
}

National Cancer Institute

\section{Source}

National Cancer Institute. Eg/ Nine Homolog 2. NCI Thesaurus. Code C131540.

EgI nine homolog 2 (407 aa, $44 \mathrm{kDa}$ ) is encoded by the human EGLN2 gene. This protein is involved in the hydroxylation of hypoxia-inducible factor alpha proteins. 